\title{
耐水性を有するイオン交換紙の製造*1
}

\author{
三菱レィヨン株式会社 宮松德久 ${ }^{* 2} \cdot$ 小口 登 $^{* 3}$
}

\section{PREPARATION OF WATER-PROOF ION EXCHANGE PAPER ${ }^{* 1}$}

\author{
By Tokuhisa Miyamatsu ${ }^{* 2}$ and Noboru Oguchi ${ }^{* 3}$ \\ (Mitsubishi Rayon Co. Ltd., Product Development Center, \\ 600 Daiko-cho, Higashi-ku, Nagoya City, Aichi Pref., Japan 461)
}

The preparation of water-proof ion exchange paper is carried out as follows:

(1) Wet paper is made of the fine fibrous ion exchanger having heat-adhesive property with TAPPI standard paper making machine. As reported in a previous paper, the skeletone of the ion exchanger is composed of high density polyethylene.

(2) After the wet paper is dried, it is treated with heat of $150^{\circ} \mathrm{C}$ for ten seconds to give water-proof properties.

The characteristics of the ion exchange paper are clarified as follows:

(a) As heat-treatment brings about adhesion between contacting points of fibrous ion exchanger, the ion exchange paper does not disperse in water even with stirring, so it can be used repeatedly.

(b) A well balanced ion exchange paper similar to filter paper is gained by adding wood pulp $30 \mathrm{wt} \%$.

(c) Ion exchange capacities of the ion exchange paper prepared under the optimum condition are as follows:

\begin{tabular}{|c|c|}
\hline $\begin{array}{l}\text { Ion exchange } \\
\text { group of I.E. Paper }\end{array}$ & $\begin{array}{c}\text { Ion exchange capacity } \\
\text { (meq/g) }\end{array}$ \\
\hline$-\mathrm{SO}_{3} \mathrm{Na}$ & 2.1 \\
\hline$-\mathrm{N}^{\oplus}<\underset{\mathrm{CH}_{3}}{\mathrm{CH}_{3}} \quad \mathrm{Cl} \ominus$ & 1.3 \\
\hline$-\mathrm{N}<-\mathrm{C}_{2} \mathrm{H}_{6}$ & 1.8 \\
\hline
\end{tabular}

(Received February 17, 1982)

*1この報文を「瀻維状イオン交換体及びその応用に関す る咞究(第 10 報), Study on fibrous ion exchanger and its application (Part 10)」とする。

*: 垷在の所监：ダイヤフロック株式会社(東京都千代 田区丸の内 1 ○ 5 \% 1 )

Present address: Dia-flock Co. Ltd.(Marunouchi, Chiyoda-ku, Tokyo, Japan 100)

*3 琴在の所湡：日本女子大学被服学科(東京都文矣区 目白台 2-8-1)

Present address: Japan Women's University (Mejirodai, Bunkyo-ku, Tokyo, Japan 112)

\section{1. 緒言}

合成パルプとして市販されている高密度ポリエチレン 製微細繊維にスチレン(またはビニルバンジルクロライ ドとジビニルベンゼンとを瀻維内共重合せしめた㣪イオ ン交換基の導入在行なって得た熱接者性を有する饵細䋐 維状イオン交換体 ${ }^{1)}$ を生原料しするイオン交換紙の製造 について検討した。 その結果, 
1. パルプを $30 \%$ 程湜抄すると地合いの良い沪紙状の イオン交换紙が得られる。

2. 乾學後， $150^{\circ} \mathrm{C} ， 10$ 秒間の熱処理を施すととによ り，水中での瀻維状イオン交換体の膨溜汇抗して水中て 㖥り返し使用可能な耐水性を付与するこよがでさる。

3. 乾燥および熱処理工程で失われるイオン交換容量 は，强境基性ア二オン交換基(第 4 級アンモニウム基)の 場含が最大で約 20\%であり，弱塩基性アニオン交換基 (ジエチルアミノメチル勘) の場合で䄪10\%, 強酸性力千 オン交換基(スルフォン酸基) ○場合は無視できる程僅か

であるととが明らかとなった。

得られるイオン交換紙は徉来の60に比心，イ才ン交 換体の泿率加著しく高く均質で，イオン交換容量委高く， 同時湿潣時の紙力が良好である等の特性を有するたか イオン交換タロマトグラフィーを始めとする分析用途の 他二次元の多孔性シート状イオン交換体としての利用が 考えられる。

\section{2. 実 戨}

\section{1 原料および薬品}

\section{(1) 原料維}

三井ゼラパック社製 SWP E-400（合成木材パルプ上 して市販されている高密度ポリチレン製フィプリル化 䋐維，平均繊維長は $0.9 \mathrm{~mm}^{2)}$ )を風乾して用いた。

(2) パルブ

硒したクラフトパルプ

(3) 誡 藥

スチレン $(\mathrm{St})$ ，ビニルペンジルクロライト $(\mathrm{VBC})$ ジビニルベンゼン (DVB) およで2２゚ーアソビスイソブチ ロニトリル（AIBN）については既報”と同じあのを用い， 他の楽器については特記しない限り試楽一級または特級 を用いだ。

\section{2 製 造}

\section{（1）ペース維維の裂造}

题紙状の原料瀻維 $500 \mathrm{~g}$ に，モノマー溶液 $650 \mathrm{cc}$ 在加 元均一に含浸させたのち無水芒硝 $10 \mathrm{~g} / \mathrm{l}$ 水溶液に投入 する。ホモミキサー(特殊袎化工業株式会社製)索用い，

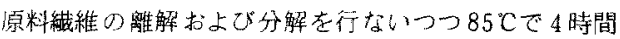
かけて重合行なう。

なお，モノマーについては子備検討り結果次の桑件を 採用した。

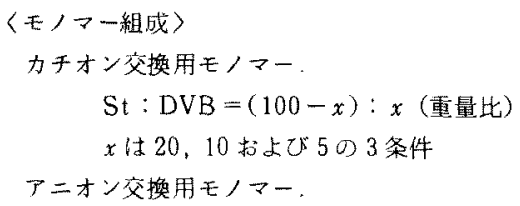

VBC : St : DVB $=81: 9: 10$ (重量比) 〈重合開始剂(AIBN) 使用翼〉

$A I B N /$ 全モ/ $\checkmark-=0.005$ (重量比)

〈モ〉マー稀粎剂お上び桸䆏倍率〉

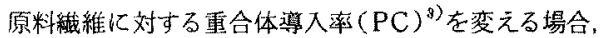
トルエンをモノマー稀瀵剂上して用いた。検討したトル エンの添加量は 50 vol \%である。

以上の条件で得られた St - DVB系およびVBC-St -DVB系ベース瀻維は，乾燥した後，次のイオン交換 基導入工程供した。

（2）イオン交換基の導入と棫維状イオン交換体(IEF) の調製

St -DVB系ベース瀻維は $98 \%$ 硫酸で処理することに より，纎維状强酸性力千オン交換体(CEF)に，また， $\mathrm{VBC}-\mathrm{St}-\mathrm{DVB}$ 系ベース緎維はトリメチルアミン処理 することにより強塩基性アニオン交換体(AEF)に，さら にジエチルアミン妈理するてとにより，ジエチルアミノメ

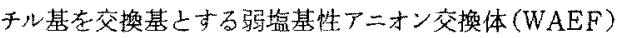
とした。

これらのイオン交换基の導入はいずれあ既報 ${ }^{1,3)}$ にし たが心実施し得ら机たIEFはCEFはNa形，AEFは Cl 形怙よびWAEFはOH形とし，脱水して密閣容器内 に保存し，使用時に所要量者固形分率上り逆算して使用 した。

\section{3 イオン交換紙の製造}

上記のIEF のいずれか一方または，これに木材パル プを加えだものを，所定量秤取し，あらかじめ水によく 分散させた後，TAPPI 標準抄紙機(熊谷理機株式会社 慗)を用いて抄紙し，得られた湿紙の両面に沪紙上パル プの厚紙をあて、プレスして余剩水を除去する。

坪䮸壮予備检討の結果 $160 \mathrm{~g} / \mathrm{m}^{2}$ を適当亡認めとれを 標倠とした。

なお，抄紙時の㵶維の凝集および沈降速度差等を改良 し，地合いを良くする目的でポりエチレングリコール系 粘剤(佮品名アルコックス，明星化成工業)在分散液に0.05 g/lo割合で添加して用い，また，水は Na 形力千ォン 交換樹脂を通して軟水化した季のを用いた。

プレスした湿紙はヤンキードライヤーを用い乾燥した。 乾燥条件は $115^{\circ} \mathrm{C} ， 90$ 秒を標集条件亡した。

最後に酎水性を与えるため, $140^{\circ} \mathrm{C} \sim 160^{\circ} \mathrm{C}$ 温度で所 定時間ヒュージングプレス機〔本来瀻維製品の熱セット を目的として製作されたものでアイロン台のように，ク ッション性のある布でカバーされたト下のボート閐に試 料を挟み，熱処理する機械 [製作 Kannegiesset \& Co. （西独），型式：XVOB，輸入：東京清水機工（株））用 い熱処理を行なった。 
2.4 得られたイオン交換紙の評価

(1) イオン交換容量の淜定

総 1オン交換容量および中性塩分解能については既 報㝵と同様にして行なった。

ただし，耐水好理したイオン交換紙は約 $3 \mathrm{~mm} \times 1 \mathrm{~mm}$ 角の小片に切りきざんで供試した。

\section{（2）酎水性の钎価}

約 $1 \mathrm{~g}$ の紙を約 $3 \mathrm{~mm} \times 1 \mathrm{~mm}$ 小片に切りきざみ，乙 の全量を約 $2 l$ 熱水中に入れ，30 分間激しく暻沸処理 したものについてその形態の崩買状況を観察して判断し た。

\section{（3）寸法変化の測定}

乾燥紙老湿らした場合 (乾 $\rightarrow$ 湿寸法翌化) 拉よび湿潤状 態加ら乾燥した場合（湿＼cjkstart乾寸法变化）について測定し t。

なお，湿 乾寸法変化の测定は約 $5 \mathrm{~cm}$ 角のサンプル を脱イオン水に浸漬した状態での寸法をまず測定し，つ いであらかじめ乾いた厚紙間で湿紙を王縮した後、サン プルを伸縮性のあるネットに委せた状態で風乾したサン プルの寸法を测定する方法によった。

\section{3. 結果および考察}

\section{1 抄紙について}

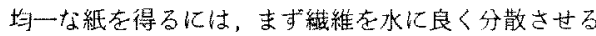
こしが前提となる。水(茾戸皮を使用)ををのまま用いる 上，凝集する傾向加子られたが沪過後 Na形力千才ン交 換樹脂力ラム存通し軟化した水壳用いるととに上り解決

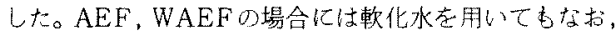
凝集が起きるばかりか疑集之同時に浮上が起きた。

よく観察すると，声佳 $1 \mathrm{~mm}$ 以下の小さな気包老核上 し，これにAEFまたはWAEFが付着し，凝集している ことが判明した。これは一昼夜放置して，微湅気泡を除 いた水を用いることにより解決できた。

$\mathrm{AEF}$ が気泡を吸着し易い原因しして，AEFがやや践 水性で，気液界面で気体に上り親和性があるか，あるい は，微小気泡と水との界面は，表面電位がマイナスにな ってアニオン交換体に吸着され易い等の要因が考えられ る。

AEFはパルプと搌抄する場合，僅かながら互いに吸 着する様汇疑集する傾问がみられた。また，一般にパル プと浘抄する場合，比重差により上下汇分離する傾向が みられた。これらの障害に対し高分子増粘剂(アルコッ クス)を $0.05 \mathrm{~g} / 1$ の割合で添加した水を用い，分散性を 改良し，得られる紙の地合いの向上老計った。

3.2 パルプとの混抄，および混抄率の決定 パルプ混抄は，紙貿の改良と工程通過性を良くする目
的で行なった。

すな和ち，IEF 100\%抄紙の場合，得ら机吉紙は币貶 の沪紙に比べて緻密で，折扎易い傾问加强かった。

これは，IEFがポリェチレン製合成パルプの中でも比

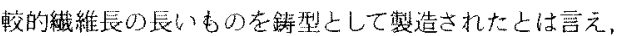

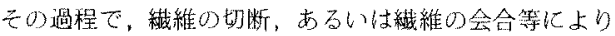

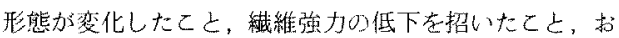
よび乾燥甫よで熱好理工程でポリエチレンり配问性が失 わ机，強力を失うため，上若えている。

また，IEF 100\%での抄紙は特汇架橋度の低いIEF を用いる場合，抄紙直後の含水率が著しく高く，湿紙を

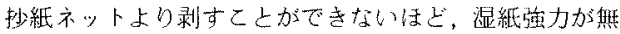
いため，緍切扎が多発した。また，湿潤状態から乾燥す る際の收樎のた好乾燥工程で紙切执や不均一化を招い た。

IEFを米独で抄紙する埸合のてれらの問題点は，此 校的瀻維長の唇いパルプを混抄することにより，效果的 に改良されることが明ら加になっ。

図1は，CEFよパルプとの泿抄紙を，無拘束状態で乾 燥した場合に捛ける，パルプの混会率上，乾燥に上る収 縮涪の関係である。架橋度加低く，膨润度の高いCEF の場合も，架橋度加高く，膨湭度の低いCEFの場合の いず㧈李，パルプ混率が高まるにつれ収維率が減少し， 特に30\%以上で取唃は、泟将一定になる。

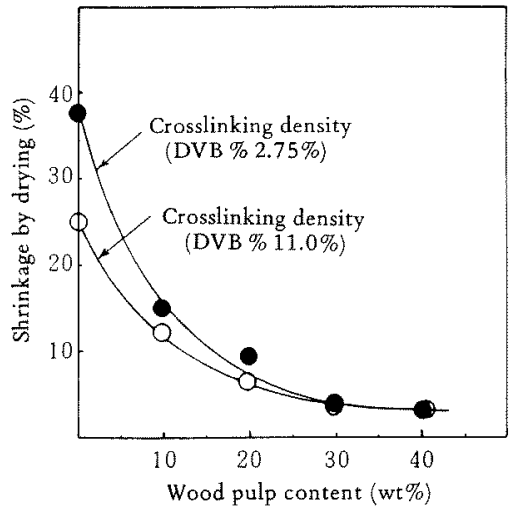

Fig. 1. Effect of wood pulp content on shrinkage of wet cation exchange paper by drying.

これは，乾燥過程で、ほとんど収繀しないパルプの䋐 維よりなる二次元ネットワークに上る取繀阻止機構がパ ルプの存在率 (混率) 加 $30 \%$ 以上になる上, 有勃桡能す るすのと考えることができる。

な扰，乾燥したIEF紙老需らした場合，面皘方向八の 伸長が生じるが，この伸長率とパルプ泿抄率しわ間には 
先の収縮摔之暀抄率よの閒で認められた同じ関係が琶め 斻た。

紙としての性賽は，パルプ混抄率が高いは上゙，良いの は当然であるが，イオン交換紙としては，一般的に異物 が少なく交換㝘量が高いことが望まれるため，パルプ混 抄率は低い方が好ましい。

幸いパルプ湜抄率 $30 \%$ で上記しだパプ㭴抄による抄 紙工程通過性り改善ばかりでなく市販の沪紙にかなり近 い地合い存するイオン交換紙加得られたので本検討に おけるパルプ湿粆率は30妿を中心に检傠した。

\section{3 乾燥および熱接着処理}

〈執燥化ついて

抄紙し，脱水した湿紙の乾燥にはヤンキードライヤー を用いた。

乾燥口ーラーの表面温度は $100^{\circ} \mathrm{C}$ 以下の場合，乾燥速 度加逯く逆に，過度に高温の場合，イオン交換基の分解等 のトラブルが予想されたので 100 - 130 C の範囲で検討 した。

その結果 $130^{\circ} \mathrm{C}$ おる゙ $110^{\circ} \mathrm{C}$ における乾燥必必要な時 間は $130^{\circ} \mathrm{C}$ で約 50 秒， $110^{\circ} \mathrm{C}$ で約 65 秒を要した。ロ一 ラ一の表面温度加 $125^{\circ} \mathrm{C} ， 130^{\circ} \mathrm{C}$ と高くなるにつれ，乾 燥を繰り返し行なうとフェルト枋よびローラー表面に IEFが局所的ではあるが，付着し，次第に付着部分が搪 大する傾向が見ら机た。

付着物老観察した上ころIEF の接着が見られた。 ーラー表面がポリエチレンの融点に近くなり弱い接着が 発生し始めたととが原因上若えら扎る。

Table 1. Relation between drying condition and ion exchange capacity.

\begin{tabular}{|c|c|c|}
\hline \multirow{2}{*}{$\begin{array}{l}\text { Ion exchange } \\
\text { group }\end{array}$} & \multicolumn{2}{|c|}{$\begin{array}{l}\text { Ion exchange capacity } \\
\text { (meq/g) }\end{array}$} \\
\cline { 2 - 3 } & before drying & after drying \\
\hline$-\mathrm{SO}_{3} \mathrm{Na}$ & 2.1 & 21 \\
\hline $\mathrm{Cl}^{\ominus}$ & & \\
$-\mathrm{N}^{\oplus}\left\langle\mathrm{CH}_{3}\right.$ & $\mathrm{CH}_{3}$ \\
$\mathrm{CH}_{3}$ & $\begin{array}{c}1.5 \\
\text { (salt stripping } \\
\text { cap.) }\end{array}$ & $\begin{array}{c}1.3 \\
\text { (salt stripping } \\
\text { cap.) }\end{array}$ \\
\hline$-\mathrm{N}\left\langle\begin{array}{c}\mathrm{C}_{2} \mathrm{H}_{5} \\
\mathrm{C}_{2} \mathrm{H}_{5}\end{array}\right.$ & 1.9 & 1.8 \\
\hline
\end{tabular}

Drying conditions

Dryer: Yankee dryer

Temp.: $115^{\circ} \mathrm{C}$ (Surface temp.)

Time: for 90 seconds

Ion exchange paper tested

Wood pulp $30 \mathrm{wt} \%$

I.E.F. $\quad 70 w t \%$
このととから，ローラー表面をより高温に保ち乾燥と 次の熱好理を一連の工程として行なうことは，付着物発 生の上からも不都合であり，さらに後述の検討上り，1 オン交換紙が高温領域に滞在する時間が長くなるととは， 特に AEF の交撸容量を低下させ好ましくない事が判明 した。このため乾燥条件は， $115^{\circ} \mathrm{C}$ ，ほぼ 65 秒間程で乾 燥古るが余裕を持たせ， $115^{\circ} \mathrm{C} ， 90$ 秒とした。

表 1 はイオン交撸紙のこの乾燥条件による乾燥前後の イオン交換容鼠老調べた結果である。強塩基性アニオン 交換紙で，中性塩分解能が，2割近く低下している点在 除けば乾燥によるイオン交換容量の低下は，ほ上んよ゙な いか，極的て䇺加でる。

〈熱接看について〉

乾燥したイオン交換紙に耐水性を与える熱接着呚理は ヒュージングプレス機を用いた。

熱接菁条件之姏理されたイオン交換紙の耐水性执よび イオン交換容淟との関係表 2 にまよお。处理条件と 得られる耐水性效果上の関連については，アニオン扰よ びカチオン間にはとんど差がなく共に $150^{\circ} \mathrm{C} １ 0$ 秒程の 姏理条件で十分である。150 $\mathrm{C}, 10$ 秒間の熱処理条件で は，イオン交換紙の変色，交換容量の低下も僅かである。

この様に極的て短時閪の処理で十分な酎水性が得られ るのは，好理装置である七ュージングプレス機が加熱空 気をイオン交換紙に謴通せしめる機構になっており，温 度上昇が瞬時に達成されるため上考えている。

なお，イオン交換体，特にIERの高温でのイオン交換

Table 2. Effects of heat-adhesive treatment on waterproof property and ion exchange capacity

\begin{tabular}{|c|c|c|c|c|c|c|}
\hline \multirow{2}{*}{$\begin{array}{l}\text { Condition of } \\
\text { heat-adhesive } \\
\text { treatment }\end{array}$} & \multicolumn{3}{|c|}{$\begin{array}{l}\text { Waterproof pro- } \\
\text { perty }\end{array}$} & \multicolumn{3}{|c|}{$\begin{array}{l}\text { Ion exchange } \\
\text { cap. (meq/g) }\end{array}$} \\
\hline & CEP & $\mathrm{AEP}$ & WAEP & $C E P$ & $\mathrm{AEP}$ & WAEP \\
\hline $130 \mathrm{C} \times 30 \mathrm{sec}$ & $\triangle$ & & & 2.1 & 1.2 & \\
\hline $140^{\circ} \mathrm{C} \times 10 \mathrm{sec}$ & $\triangle$ & & & 2.1 & 1.2 & \\
\hline $140^{\circ} \mathrm{C} \times 30 \mathrm{sec}$ & 0 & & & 2.1 & 1.1 & \\
\hline $150^{\circ} \mathrm{C} \times 5 \mathrm{sec}$. & $O \sim \Delta$ & & & 21 & 1.2 & \\
\hline $150^{\circ} \mathrm{C} \times 10^{\circ} \mathrm{sec}$ & 0 & 0 & 0 & 2.1 & 1.2 & 1.7 \\
\hline $150 \mathrm{C} \times 30 \mathrm{sec}$ & 0 & & & 2.1 & 1.0 & \\
\hline $160^{\circ} \mathrm{C} \times 5 \mathrm{sec}$. & 0 & & & 2.1 & 1.2 & \\
\hline $160^{\circ} \mathrm{C} \times 30 \mathrm{sec}$. & 0 & & & 2.1 & 0.7 & \\
\hline non treatment & $\Delta$ & $\Delta$ & $\Delta$ & 2.1 & 1.3 & 1.8 \\
\hline
\end{tabular}

${ }^{*} O:$ good waterproof property ${ }^{* *}$ Salt stripping cap. $\triangle$ : poor waterproof property

$\triangle$ no waterproof property

IEF used as raw material

Crosslinking density : DVB $5.5 \%$

Content ratio in IEP: $70 w t \%$ 
容量保持率については，多くの報告”があるが，ほ上ん ご水中または，湿閏状態での分解に関するものて，乾燥 状態での試験は極めて少ない。

田村ら゙は、スチレン系IER粉末をポリプロピレンと $180^{\circ} \mathrm{C}$ 熱ロールで混練り缓，プレス成形機で， $220^{\circ} \mathrm{C}$ で製膜し，ポリプロピレン系不均質イオン交撸膜の製造 を行なっている。その過程で失われたイオン交換容量は 強酸性力千丈ン交換樹脂( $\mathrm{Na}$ 形)で $0 \sim 5 \%$ ，強塩基性了二 オン交換樹脂(Diaion PA-316, Cl 形)の場合総イオン 交換签量で約 $11 \%$ ，中性塩分解能で $74.4 \%$ ，さらに二級 アミ/基を交換基とするDiaion WA-300場合で，22 名弱であるこよを報告している。

この報告に比べ，最終の熱接着工程でイオン交換容 壆の損失が少ない理由として，処理時間が極好て短いこ との他，前の乾燥工程で一度熱屓歴を受けていることが 影整しているよ考えている。

乾燥工程と熱接算工程で失われたイオン交換容量は, $\mathrm{AEF}(\mathrm{Cl}$ 形) の総イオン交換容量で 10\%，中性塩分解 能になると，20\%に達し，WAEF(OH形)で10.5\%であ る。一方, $\mathrm{CEF}$ ( Na 形)は，イォン交換容量の低下は兒 られなかった。

\section{4 得られたイオン交換紙の特幑}

得られたイオン交換紙のイオン交換容鰋については， 乾燥放よび熱接着条件との関連で言及したのでここでは， その他の点について考察する。
〈寸法変化求上び酒过水性〉

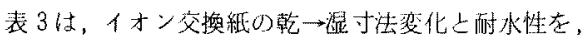
その棈成成狈之の関連で調へた結果である。とれより， 乾 $\rightarrow$ 湿寸法变化比しては，

1. 面方向の寸法変化はパルブ涅抄率 $30 \%$ 执よび 70 若共極めて少なく，しかむ活上んど差が無い。

2. これに比べ厚さの增加は，かなり大きいしが注 目される。

これは，慗造時の乾爆条件に起因する上考えられる。 すなわち，乾燥に用いたヤンキードライヤーは，加熱 ドラムとフメルトの間に湿紙を挟んで乾燥老行なうタイ プであり、したがって乾燥に伴い元来，収箱する性質の

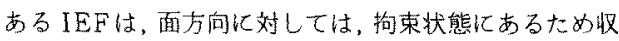
繀しない。一方，厚さ方向に対しては，顼縮されつつ乾 燥が行ないれる。

したがって，得られだオン交換紙が水に浸漬される とはよんと湿紙の状態に离るため，面方向に対しては，

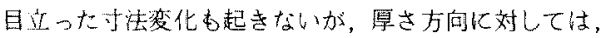
IEFの膨聞加そのまま厚さの增大に寄与するものと考 えるとよができる。

PCO高いIEF混挑紙の乾》湿暻さの增加は大きい が，架橋度の高いIEF混抄紙では小さい等，IEFの膨

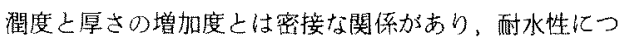
いて古，膨潤度 (架橋度)の影㗽が大きく、膨閏度が低い 程，耐水性が良好であることが明らかとなった。

Fig. 3. Property of cation exchange paper and its components.

\begin{tabular}{|c|c|c|c|c|c|c|}
\hline \multirow{3}{*}{$\begin{array}{c}\text { Sample } \\
\text { No. }\end{array}$} & \multicolumn{2}{|c|}{ CEF as raw material } & \multirow{3}{*}{$\begin{array}{c}\text { Wood pulp } \\
\text { content } \\
(\%)\end{array}$} & \multirow{2}{*}{\multicolumn{2}{|c|}{$\begin{array}{l}\text { Dimension increase } \\
(\%, \text { Dr } y \rightarrow \text { Wet state })\end{array}$}} & \multirow{3}{*}{$\begin{array}{l}\text { Waterprool } \\
\text { property* }\end{array}$} \\
\hline & \multirow{2}{*}{$\mathrm{PC}(\%)$} & \multirow{2}{*}{$\begin{array}{l}\text { Crosslinking } \\
\text { density (DVB } \%)\end{array}$} & & & & \\
\hline & & & & Plane & Thickness & \\
\hline A & 118 & 11.0 & 30 & 3.8 & 26 & 0 \\
\hline B & 118 & 11.0 & 70 & 1.2 & 12 & 0 \\
\hline $\mathrm{C}$ & 120 & 2.75 & 30 & 4.0 & 58 & $0 \sim \triangle$ \\
\hline $\mathrm{D}$ & 120 & 2.75 & 70 & 1.3 & 20 & $\Delta$ \\
\hline$E$ & 55 & 275 & 70 & 1.2 & 14 & 0 \\
\hline
\end{tabular}

* Same as Table 2.

Table 4. Dimensional changes after repetition of wetting and drying of cation exchange paper*

\begin{tabular}{|c|c|c|c|c|}
\hline \multirow{2}{*}{$\begin{array}{l}\text { Times of } \\
\text { repetition }\end{array}$} & \multicolumn{4}{|c|}{ Dimension change ratio ${ }^{\text {** }}(\boldsymbol{\phi})$} \\
\cline { 2 - 5 } & plane direction & thickness direction & plane direction & thickness direction \\
\hline 0 & 0 (reference) & 0 (reference) & 3.8 & 26 \\
\hline 1 & -1.2 & 18 & 3.7 & 25 \\
\hline 2 & -1.6 & 20 & 3.6 & 26 \\
\hline 3 & -1.4 & 20 & 3.8 & 28 \\
\hline
\end{tabular}

* Cation exchange paper tested: Sample A in Table 3.

** Measured on basis of original dry cation exchange paper. 
表 4 は繰り返し使用される場合を想定し, 表 3 Aの試 料について,さらに風乾 $\rightarrow$ 水浸漬を繰り返しその間の寸 法变化を追跡した結果である。

面方向の寸法については, 乾燥状態の寸法に比べ, 湿 潤状態の寸法が僅かながら大きいが, 湿 $\rightarrow$ 乾の繰り返し 回数に対しては安定している。

また, 厚さ方向については, 最初の水浸漬により大き く増大するが以後, 乾・湿の厚さの差も少なくなり, 湿 乾の繰り返し処理による影響もほとんどみられない。

イオン交換紙はほ上んどの場合, 湿潤状態で使用され るおのであり, 寸法変化についても湿状態についてのみ 考虑すればよいと考えられる。この意味において, 最初 の水浸漬により紙厚の增大がかなり大きいととは，まず 障害になるととはない様に思わ㧈る。

なお，この繰り返し試験の間耐水性は目立った変化が みられなかった。

以上の結果から本法で得られるイオン交換紙は, 繰り 返し使用汇耐える耐水性亡寸法安定性を備えていると考 える。

〈イオン交換紙の構造〉

イオン交換紙として市販されているあのに微粒 IERま たは，IER粉末をパルプと共に抄き込んだあの(図2)が ある。IERはパルプの䋐維間陌に単に保持されただけで あり, 軽く吒けば勿論, 簡単な摩擦によっても, 樹脂の 脱落, 移動が起きる。これに比べ本法で得られるイオン 交換紙(図3)は，実質的にパルプの形状をしたIEFよ り構成されており，イオン交換体の混率の高さ，分布の 均一性, 存在の連続性, さらにその安定性においても好 ましい状態にあると言える。

また、イオン交換セルロースをパルプと混抄したイオ ン交換紙も市販されている。これらのイオン交換紙 ${ }^{6,7,8)}$ に比べ本報で得られるものはイオン交換容量が高く, 耐 水性，耐薬品性に優れた特徵がある。

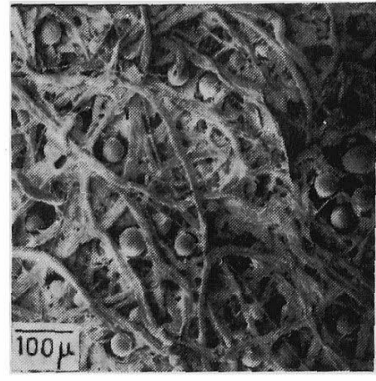

Fig. 2. Scanning electron micrograph of surface of ion-exchange paper, product of Miles Laboratories, U.S.A.

\section{4. 結語}

合成パルプとして市販されている高密度ポリエチレン 製微細繊維にスチレン(またはビニルベンジルクロライ ド)とジビニルベンゼンとを縬維内重合させた後、イオ ン交換基の導入を行なって得た熱接着性を有する微細繊 維状イオン交換体を主原料として用いたイオン交換紙の 製造について検討した。

その結果

1. パルプを $30 \%$ 程混抄すると, 地合いの良い沪紙状 のバランスのとれたイオン交換が得られる。

2. さらに乾燥後，10秒間程の熱処理を行なうこと により，繰り返し使用可能な耐水性を付与することがで きる。

3. 乾燥抽よび熱処理工程で失われるイオン交換容量 は，強塩基性アニオン交換基(第 4 級アンモニウム基)の 場合が最大で約 20\%, 弱塩基性アニオン交換基(ジェチ ルアミノメチル基) の場合で約 $10 \%$ ，強塩基性力チオ ン交換基(スルフォン酸基)の場合は，無視できるほど僅

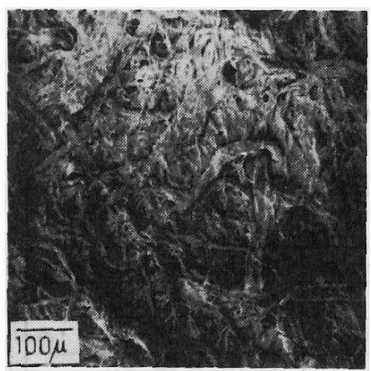

(a)

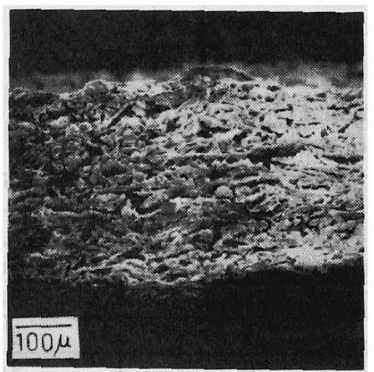

(b)

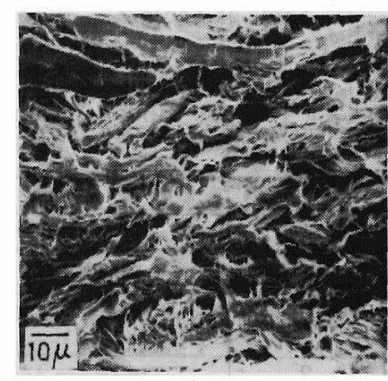

(c)

Fig. 3. Scanning electron micrograph of ion exchange paper: surface (a), cross-section (b) and (c). 
かであることが明らかになった。

得られるイオン交換紙は従来の古のに比べイオン交換 容量屯高く，同時汇湿闑時の紙力が良好であるなどの特 性を有するため。イオン交換クロマトグラフィーを始め 之する分析用途の他, 二次元の多孔性イオン交換体とし ての利用が考えられる。

終りに本研究の発表索許可して下さった三菱レイヨン 株式会社，および実験に助力された三菱レイヨン(株)商 品開発研究所の山本省吾研究員, および宮本多加子氏に 心より感謝の意を表します。
文献

1）宮松德久，小口 登，瀻学誌，36、T-364（1980）

2）三井ゼラパック株式会社，SWP説明筫料

3）宮松德久，小口 登，織学誌，36，T-208 (1980)

4) 例えば久山 宏, 高見沢行雄，肥後崎信行，日化誌 10,2020 (1979)

5）田村紀義，坦花秀武，日化誌，No.2，284（1976）

6）東洋䂗緍K.K. . 「東洋イオン交换沪紙」, 説明武料

7）フナコシ薬品株式会社，フナコシ技術レポート，ワ ットマン，イオン交換セルロース（その1〜その17）

8）住友化学工業株式会社，“金属イオン捕招用滤紙厂工 クスパピール゙，PR資料 